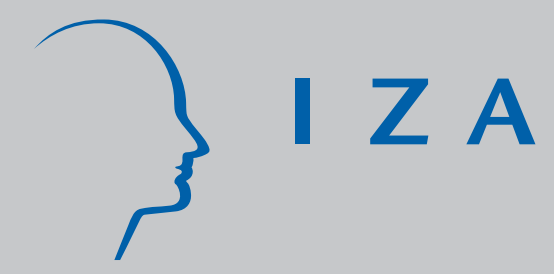

IZA DP No. 689

The Effects of Union Wage-Settings on Firms' Production Factor Decisions

Almas Heshmati

Ilham Haouas

J anuary 2003 


\title{
The Effects of Union Wage-Settings on Firms' Production Factor Decisions
}

\author{
Almas Heshmati \\ WIDER, United Nations University \\ and IZA Bonn \\ Ilham Haouas \\ TEAM, Université Paris I Panthéon-Sorbonne \\ Discussion Paper No. 689 \\ January 2003 \\ IZA \\ P.O. Box 7240 \\ D-53072 Bonn \\ Germany \\ Tel.: +49-228-3894-0 \\ Fax: +49-228-3894-210 \\ Email: iza@iza.org
}

This Discussion Paper is issued within the framework of IZA's research area The Future of Labor. Any opinions expressed here are those of the author(s) and not those of the institute. Research disseminated by IZA may include views on policy, but the institute itself takes no institutional policy positions.

The Institute for the Study of Labor (IZA) in Bonn is a local and virtual international research center and a place of communication between science, politics and business. IZA is an independent, nonprofit limited liability company (Gesellschaft mit beschränkter Haftung) supported by the Deutsche Post AG. The center is associated with the University of Bonn and offers a stimulating research environment through its research networks, research support, and visitors and doctoral programs. IZA engages in (i) original and internationally competitive research in all fields of labor economics, (ii) development of policy concepts, and (iii) dissemination of research results and concepts to the interested public. The current research program deals with (1) mobility and flexibility of labor, (2) internationalization of labor markets, (3) welfare state and labor market, (4) labor markets in transition countries, (5) the future of labor, (6) evaluation of labor market policies and projects and (7) general labor economics.

IZA Discussion Papers often represent preliminary work and are circulated to encourage discussion. Citation of such a paper should account for its provisional character. A revised version may be available on the IZA website (www.iza.org) or directly from the author. 
IZA Discussion Paper No. 689 January 2003

\title{
ABSTRACT \\ The Effects of Union Wage-Settings on Firms' Production Factor Decisions
}

This study is concerned with the development of a theoretical model and its empirical application to the estimation of the interaction between firms and trade union in determining wages and employment. The focus is on analyzing the effects of unions' demands on the firm's choice of factors of production. In a two-step process the union and firm determine wages and capital stock, conditional on which the firm decides on production factors of employment, working hours and capital operating time. We suggest the use of a panel data approach applied to manufacturing data. A dynamic model is specified in which the optimal levels of the variables of interest and the speed of their adjustments are modeled in terms of observable policy variables.

JEL Classification: $\quad$ C33, D21, E24, J50, L60

Keywords: wage bargaining, employment, capital stock, work hours, capital operating time, manufacturing, panel data

Corresponding author:

\author{
Almas Heshmati \\ UNU/WIDER \\ United Nations University \\ Katajanokanlaituri 6B \\ 00160 Helsinki \\ Finland \\ Tel.: +358961599 212 \\ Fax: +385961599333
}

Email: Almas.Heshmati@wider.unu.edu 


\section{Introduction}

In the literature of industrial organization and labor economics, much attention has been paid to the economic behavior of trade unions with the main focus on the determination of wages and employment. ${ }^{1}$ This is due to the fact that a large fraction of the labor force in developed economies is unionized. The employment performance differs among industrialized countries. In general the cyclical earning variability is greater than cyclical employment variability in response to exogenous shift in the employment demand function. The employment-wage relationship is considered as one of the main factors explaining the differences in employment performance among those countries. The degree of unionization and the subsequent rigidity of the labor market explain the high unemployment rate and real wages consistently exceeding the market clearing levels. In such environment real wages might rise leading to an inefficiently high and somewhat persistent level of unemployment.

The economic research on union's behavior is classified into three groups of models: the monopoly union, the efficient bargain and the right to manage models. ${ }^{2}$ These models originate from the research analyzing the relationship between trade union and firms. Oswald (1982a) developed a model where the monopoly trade union sets the wage, and the firm employment. However, the theoretical literature of the above relationship ${ }^{3}$ have the shortcoming of not taking into account the effects of unions wage-settings on the firm's choice of other factors of production. This omission can be serious if trade union behavior has implications for instance for the firm's investment, choice of capital stock, work and capital operating hour decisions.

In an attempt to take into account the impact of union's wage demand on firm's production factor decisions, Anderson and Devereux (1988) added an extra dimension namely the firm's choice of capital stock to the Oswald model. This extended model can be interpreted as a simple non-cooperative game between the trade union and firm, where the two parts relative power or their degree of strategic dominance is crucial to the outcome of the game. In the case of union dominance (Stackelberg leader) they find that the wage is lower and employment level higher than under the Nash equilibrium (neither player is strategically dominant). When the dominance role is reversed, the wage is again lower, but the employment and capital stock may be greater or less than under the Nash equilibrium. Their findings is in contrast with models such as in Calmfors and Horn (1985) where a dominant union cause a higher real wage and lower employment. If the trade union contract structure are primarily concerned with wage rate with no restrictions on the firm's determination of employment the presence of monopoly trade unions might lead to adverse welfare effects than in models which abstract from the firm's investment decisions. ${ }^{4}$

Pencavel and Holmlund (1988) provided a behavioral foundation for the monopoly trade union administrated wage modeled jointly with the determination of employment

\footnotetext{
${ }^{1}$ For surveys see e.g. Dertouzos and Pencavel (1981) and Oswald (1982a, 1982b, 1985).

${ }^{2}$ For a comparison and discrimination between the models see MaCurdy and Pencavel (1986).

${ }^{3}$ See Oswald (1982a, 1982b, 1985), Grossman (1983) and Lawrence and Lawrence (1985).

4 For a selection of papers on the issues discussed above see e.g. Dertouzos and Pencavel (1981), Calmfors (1982), Nickell and Andrews (1983), Pencavel (1984, 1985), McDonald and Solow (1981), Horn and Svensson (1986) and Nickell (1986).
} 
and hours of work. Inclusion of hours of work was motivated by the fact that variations in labor use in production involves changes both in employment and in hours worked per employee. Growth in the fixed cost of hiring and training labor compared to total labor cost encourages employers to substitute hours of work for number of workers. The authors present some evidence on the behavior of employment and hours of work of blue-collar workers in Swedish mining sector.

In Swedish economy the wage setting is highly centralized in which the confederation of unions and employers negotiate to set wages throughout the sector. The labor union acts as wage leader in wage determination and the employers follow in setting employment and hours of work. Although the model developed is adapted to the characteristics of the Swedish economy, the authors conclude that a number of factors were omitted in the model specification and estimation reducing the confidence of their estimation results. The empirical results suggest that the objectives of the trade union is crucial to the effects of exogenous shocks in the employment demand function on wages, employment and hours of work. The union's objectives explain the relative inflexibility of real wages over the business cycle compared to the greater pro-cyclical movements in employment. The estimates provide strong support for the existence of negative relationship between employment and wages, but only week support for negative relationship between hours of work and wages.

In a recent paper Holm, Honkapohja and Koskela (1994) developed the Anderson and Devereux (1988) Nash equilibrium model of wage and employment determination, to augment investment and capital stock decisions by the firm. ${ }^{5}$ The model nests the more conventional specifications derived from the neoclassical theory of investment and demand-supply theory of labor markets. The model is estimated as a dynamic system of equations, using Finnish manufacturing panel data. The authors conclude that their model performs well with no signs of misspecifications, it produces reasonable coefficient estimates and other properties of the model are in conformity with the theoretical reasoning. Various tests performed show that a recursive determination of hours of work specified conditional on the wage-capital stock game outperforms alternative specifications by the conventional theory of the demand for factors of production.

This paper is organized as follows. In Section 2 the generalized wage-employment model is discussed. Section 3 outlines the theoretical model. The importance of panel data is discussed in Section 4. The model applicability, its estimation and testing is discussed in Section 5. The data requirement in general and panel data in particular is presented in Section 6. The usefulness of the results is listed in the final Section of 7.

\section{The Generalized Wage-Employment Determination Model}

The primary objective of this study is to develop a theoretical model and empirically estimate the interaction between firms and trade union in determining wages, employment, capital stock, work hours and capital operating time. The model is a generalization of the Oswald (1982a) model introduced to analyze the relationship

\footnotetext{
5 The distinguishing feature of Holm, Honkapohja and Koskela (1994) model compared to the Pencavel and Holmlund (1988) is that the former was instead of work hours augmented with respect to capital stock.
} 
between trade union and firms in setting wages and employment. However, the theoretical model of the above relationship did not take into account the effects of union's wage-settings on the firm's choice of other factors of production. This omission was shown in Pencavel and Holmlund (1988) and Holm, Honkapohja and Koskela (1994) to be serious if trade union behavior has implications for the firm's work and capital operating time decisions and their choice of capital stock.

We introduce a generalization of the models introduced above which have contributions to the literature of wage and employment determination in a number of ways. First, the augmentation used here, in addition to capital stock and work hours, incorporates capital operating hours. Second, we propose a panel data approach instead of time series method to estimate the model. Third, a dynamic adjustment model is proposed where optimal level of key variables are estimated and the speed of adjustment towards optimal levels is firm- and time-specific and specified in terms of decision and policy variables. Fourth, the model is applicable to a case with wage-setting structure consistent with the model set up and the theoretical reasoning. Fifth, for our empirical application we recommend the use of manufacturing industry panel data.

\section{The Theoretical Model}

A model of wage-employment determination is formulated based on the notion of a centralized wage formation case. In a two-step process the trade union and firms determine wages and the investment, after which the firm decides on employment, work hours and capital operating time unilaterally, given wages and capital stock. The new strategic variables in the game compared to standard frameworks in the literature on trade unions and wage formations are investment and work and capital operating hours. The firms are assumed to be profit maximizers where the profit function is given by the following relationship

$$
\pi=q Y-r K-(1+s) w L
$$

where $q$ is the producer price, $Y=f(K, L)$ is the production function, $r$ is the cost of capital $(K), w$ is the wage rate of labor $(L)$ and $s$ is the payroll taxes. The trade union whose members are employed by the firm is assumed to maximize the expected utility from the after tax wage and employment benefits. The weighted average earning is expressed as

$$
w=\left[u\left(\kappa_{e}(1-\tau) w+\kappa_{u}(\bar{L}-L) b\right) / p\right]
$$

where the weights $\left(\kappa_{e}, \kappa_{u}\right)$, are employment and unemployment rate, $\tau$ is the income tax rate, $b$ is the unemployment benefit, $\bar{L}$ and $L$ are the total and employed (unionized) labor force, and $p$ is consumer price index.

The model is solved by the firm optimizing the level of employment, work and capital hours given wages and capital stock, such that the marginal revenue from producing an extra unit of output $(Y)$ is equal to the marginal cost of producing it. The conditional or short run labor demand $(L)$, work $(H)$ and capital operating hour $(N)$ functions are

$$
\begin{aligned}
& L=l\left\lfloor(1+s) w, Z^{L}, K\right\rfloor \\
& H=h\left\lfloor(1+s) w, Z^{H}, K\right\rfloor
\end{aligned}
$$




$$
N=n\left\lfloor(1+s) w, Z^{N}, K\right\rfloor
$$

where $Z$ are variables describing the position of the demand curve faced by the firm. In the first stage of the game the firm and the union decide on capital $(K)$ and wage $(w)$, taking the other player's decision variable as given. The relations in (3a-3c) are constraints in the player's optimization to achieve equilibrium. Thus, the firm's decision problem is to maximize profit (1) subject to capital, employment, work hours and capital operating hours and taking wages as given. This gives the optimality condition defining the firm's reaction function written as

$$
M(w, K, Z, r, s)=0 .
$$

Similarly, the union optimizes wage (2) subject to employment, work hours, capital operating time (3a-3c) and taking the capital stock as exogenously given. The first order condition defines the union's reaction function expressed as

$$
G(w, s, K, Z, p, \tau, b)=0
$$

where $G($.$) is dependent of consumer prices, income and payroll taxes and$ unemployment benefit but independent of the cost of capital. The Nash equilibrium is then the solution to the system of equation (4) and (5). After having the equilibrium value of capital and wages solved, the employment and work and capital operating hours are given by equations $(3 \mathrm{a}-3 \mathrm{c})$. For details on the derivation of the theoretical model without capital operating time, the comparative static properties of the equilibrium and the expected effects of a shift in the exogenous variables on wages, capital and employment see Holm, Honkapohja and Koskela (1994).

\section{Panel Data Analysis}

For application of the model outlined above we propose the use of panel data. The panel data approach has a number of advantages over time series analysis. First, the number of observations is a multiple function of the number of manufacturing sub-sectors. Second, unlike time series, the panel data do not suffer from aggregation problem. Third, the restricted assumptions of homogenous reaction functions within the manufacturing industry are replaced with a heterogeneous reaction function in the process of wage and employment setting. A dynamic model is specified where the variables of interest are functions of their optimal levels. The optimal levels and the speed of adjustment toward optimal levels are modeled in terms of observable variables and sector- and timespecific effects.

The use of panel data is highly interesting because it coincides with major changes taking place in the energy prices, capital market and the wage bargaining structure. Panel data allow us to model the temporal patterns of union and firms behavior and relate them to the exogenous change in the environment such as oil crisis, capital market, labor market policy, business cycles and the players objectives. Heterogeneity in the optimality of key variables, the gap between observed and optimal, and the speed of adjustment allow for identification of measures and calculation of their cost that has implication for design of policy directed to single industrial sectors. The costs associated with such a policy is expected to be much lower compared to an unspecified policy that in addition to having smaller impact possibly induces negative side effects. 
Introduction of heterogeneity in the analysis of wage-employment relationship is important, because industrial sectors differ in their sensitiveness to exogenous factors such as business cycles considering the timing and effects. It is also consistent with the recent tendencies towards a decentralization of the wage bargaining and the firms' relocation of production primarily for wages, taxes and trade policy reasons. The assumptions of homogeneous effects can have serious implications for the properties of the parameter estimates, inferences and policy conclusions drawn based on such a results. For instance, during recent decades both relative wages and employment has continuously been declining in the textile industry without necessarily having association with the patterns of business cycles. Another extreme case is the information technology industry, where both wages and employment independent of business cycles has been continuously increasing. While the paper and pulp industry depends heavily on the development of exchange rate and the business cycle in the trade partner countries.

\section{Estimation and Testing Procedures}

In this section we discuss the issues of specification, estimation and testing of the system of five equations determining the capital stock, wages, employment and work and capital operating hours. Under ideal conditions the observed decision variable, e.g. employment or wage should not differ, i.e. $Y_{i t}^{*}=Y_{i t}$. In a dynamic setting this implies that $Y_{i t}^{*}-Y_{i, t-1}=Y_{i t}-Y_{i, t-1}$. However, if adjustments for cost reasons and imperfections in the market are costly, firms may not find it optimal to adjust fully, but only adjust partially

$$
Y_{i t}^{*}-Y_{i, t-1}=\lambda_{i t}\left(Y_{i t}-Y_{i, t-1}\right)
$$

where $\lambda_{i t}$ is the adjustment parameter representing desired adjustment or the rate of convergence of $Y_{i t}$ to $Y_{i t}^{*}$. If $\lambda_{i t}=1$, entire adjustment is made in one period, the firm is in its target level. If $\lambda_{i t}<1$ adjustment from year $t-1$ to year $t$ falls short of the required adjustment. If $\lambda_{i t}>1$ the firm over adjusts and still not at optimal level.

As mentioned earlier, the decisions are taken in a two step process, where wages and capital stock are determined simultaneously, conditional on which the employment and work and capital operating hours are determined. Assuming a log linear functional form the equilibrium system of five equations with optimal levels of the key variables may be expressed as

$$
\ln Y_{i t}^{*}=\beta_{0}^{Y}+\sum_{j} \beta_{j}^{Y} \ln Z_{j i t}^{Y}+\beta_{w}^{Y} \ln w_{i t}^{*}+\beta_{K}^{Y} \ln K_{i t}^{*}+e_{i t}^{Y}
$$

where the subscripts $i$ and $t$ indexes the industry and time periods, the superscript $Y$ indexes decision variable, $Z^{Y}=\left(Z^{K}, Z^{w}, Z^{L}, Z^{H}, Z^{N}\right)$ represents vectors of variables that determine the optimal levels of the key variables, $Y=(K, w)$ in the first step and $Y=(L, H, N)$ in the second step. The explanatory variables containing the $Z$ vectors are partially overlapping. The actual levels of the system of five key variables are then related to their optimal levels in a partial dynamic adjustment process as follows (see also Nickell (1986) and Kidd and Oswald (1987) for details) 


$$
\ln Y_{i t}=\left(1-\lambda^{Y}\right) \ln Y_{i . t-1}+\lambda^{Y} \ln Y_{i t}^{*}+u_{i t}^{Y}
$$

in which adjustment of the key variables towards their optimal level are modeled in a panel data context. The $u^{Y}=\left(u^{K}, u^{w}, u^{L}, u^{H}, u^{N}\right)$ refer to the error terms appended to the system of equations (7) specified as a two way error component structure

$$
u_{i t}^{Y}=\mu_{i}^{Y}+v_{t}^{Y}+\omega_{i t}^{Y}
$$

where $\mu_{i}, v_{t}$ and $\omega_{i t}$ are unobservable industry-specific effects, time-specific effects, and random industry and time-specific effects or variables omitted from the system of equations. Following Kumbhakar, Heshmati and Hjalmarsson (2002) the adjustment parameter in the system, $\lambda$, are both industry- and time-varying specified in terms of both observable and unobservable factors

$$
\lambda_{i t}^{Y}=\gamma_{0}^{Y}+\sum_{i} \gamma_{i}^{Y} Z_{i}^{Y}+\sum_{t} \gamma_{t}^{Y} Z_{t}^{Y}+\sum_{m} \gamma_{m}^{Y} \ln Z_{m i t}^{Y}
$$

The variables $Z^{Y}=\left(Z_{i}^{Y}, Z_{t}^{Y}, Z_{i t}^{Y}\right)$ are vectors of industry, time, and industry- and timevariant variables determining the speed of adjustment in the actual variables towards their optimal level. It should be noted that the industry- and time-specific effects in the optimal and adjustment rates differ. By including those variables we control for possible differences in the optimal levels and the speed of adjustments in the key variables among industries and over time. The (absolute) distance between the optimal and observed levels, $\left|Y_{i t}^{*}-Y_{i, t-1}\right|$, can be used to explain variations in the speed of adjustment. The likelihood of adjustment is a positive function of the difference between optimal and observed levels. High fixed costs of adjustment might increase with the magnitude of the deviation from the desired. The relationship between the rate of adjustment and distance may be negative indicating that firms adjust the key variable when deviations are sufficiently large. Size of firm is a key variable in the adjustment process. The ratio $\left(Y_{i t}^{*} / Y_{i t}\right)$ is used to measure the degree of optimality in the variables of interest or efficiency of firms in achieving optimal levels of employment, wages, capital stock, capital operating hours and hours of work.

The system of equations in (8) accounting for (7) and (10) is estimated in a simultaneous non-linear framework using three-stage least squares or preferably generalized methods of moment estimation methods. Non-linearity arises in the parameters. A number of special cases of the adjustment parameters can be considered and tested using likelihood ratio tests. First, a case when $\lambda_{i t}=\gamma_{0}$ thereby meaning that the adjustment parameters are the same for all industries and all years as it is in the traditional dynamic partial adjustment models. Second, a case where $\lambda_{i t}=\lambda_{i}$ ( or $\lambda_{i t}=\lambda_{t}$ ), $\lambda$ is the same for all industries (or time periods) but it varies over time (industries). A third special case is $\lambda_{i t}=1$ which implies that there is no difference between optimal and actual levels of the key variables. The model is reduced to a static case where the variables are instantaneously adjusted to their optimal levels. Fourth, the first case with a constant adjustment parameter but applied to aggregate data reduces to the basic time series based model.

In addition to the special cases mentioned above related to the adjustment rate and levels of aggregation, one can perform tests for imposed restrictions regarding 
constancy of the slope parameter estimates across equations, structural breaks, exogenous or endogenous treatment of the key variables, stationarity of the process, poolability of the data, fixed or random (homoscedastic/heteroscedastic) treatment of the industry- and time-specific effects, structures imposed on the error variances and their variance components, functional form used and finally the use of one or two-step estimation (decision) procedures.

\section{Manufacturing Data Requirements}

The data to be used in an application of the model outlined above can be obtained from various publications of industrial statistics and national accounts. Ideally it should cover the three-digit industries in the manufacturing sector during a relatively long period. The data can be balanced or unbalanced but consecutively observed for a number of years.

The data set should include information on output, consumer and producer price indexes, input quantity, input prices, input costs, and a number of variables characterizing the industries and the labor market. The production variables include information on sales, value added, and an index representing the volume of industrial production. The value added and sales be measured in monetary terms and converted to fixed prices, while the volume index of industrial production be constructed using the production level in the base year.

In construction of input variables one should apply the traditional capitallabor-material energy (KLEM) approach. The corresponding approach for service industries is KLMES where $S$ indicates purchase of services. The net real capital stock to be calculated by the perpetual inventory method. In construction of the capital stock one has to account for the expected lifetime of capital stock. The price of capital to be calculated as weighted average price of building and machinery where the weights are the shares of stock of machinery and buildings capital. It must be transformed to fixed values using the producer price index. The user cost of capital can be calculated as the sum of depreciation, the interest rate and maintenance expenses.

Labor is measured both as number of full time employees as well as number of hours worked. The employment variable is a full time equivalent aggregate number of salaried employees and wage earners. The hours worked is measured as aggregate work hours by blue- and white-collar workers as well as home workers and outsiders. The hourly wages is calculated as the ratio of total compensation to labor divided by total hours worked. In calculation of the total cost of labor the payroll taxes are accounted for.

The energy input is often composed of the two main electricity and fuel components. The fuel can further be decomposed into consumption of oil, petrol and two types of heating oils. The input quantity of energy is an aggregate of fuel and electricity types expressed in common units of measurement, $M W h$. The price of energy is obtained using weighted average prices of different energy components, where each components price is obtained using the ratio of its expenditure on the energy equivalent quantity used. The energy price can alternatively be obtained as the ratio of total expenditure on energy and the quantity energy used measured in $M W h$.

Material is an aggregate measure of all expenditures associated with the use of raw materials, packing materials and hired transportation. The cost of material input is 
expressed in fixed prices using the producer price index. The total operation cost, is the sum of user cost of capital, and cost of labor, energy and material.

The data contains a number of variables characterizing the industrial sectors and the labor market. Access to information on the female share of labor force, the average over time and average shift bonus, the share of overtime of total hours worked, number of hours worked on day shift, on two shifts, on discontinuous or continuous three shifts, respectively is necessary. Using the shift variables we can construct the capital operating time for each manufacturing sub-sector. For each sector access to information on the distribution of the size of plants based on the number of employees at each place of work is required. In addition to the variables mentioned above one must use industrial sector and time specific dummies to capture unobservable sector- and technology-effects.

To the production data described above is to be added information on a number of mainly sector invariant variables used in the estimation of the system of equations. Among the variables of interest are: capacity utilization rate, export market share, investment plans, realized investment, gross national product, average contract wage, tax depreciation rate of capital, corporate income tax rate, marginal tax rate, unemployment insurance benefit, expected rate of change in price of investment, and capital stock forecast. Heshmati (2003) provides a detailed analysis of the measurement of inputs and outputs in manufacturing and service sectors.

\section{Usefulness of the Results}

This study is expected to give theoretical, methodological and guidelines to empirical contributions to the literature of trade union and firm relationship in determining wages, employment, stock of capital, work hours and capital operating time. The theoretical contribution is associated with the introduction of the production factors of capital operating time in the decision process. The main methodological contributions lie in the use of a flexible dynamic partial adjustment model. The determinants of optimal levels are identified, the optimal levels are estimated, and the speed of adjustment towards optimal level of variables of interest is both industry- and time-varying. The application on disaggregate manufacturing data during a period coinciding with major changes taking place in the energy prices, capital market and the wage bargaining structure is an important comparative advantage on the empirical side. Introduction of industry heterogeneity in the decision process and the use of up to date panel data techniques make the results highly relevant and interesting. The usefulness of the results lies in the close association with recent trends of changes in the bargaining structure and relocation of production by firms with major impact on the employment and welfare of citizens.

\section{REFERENCES}

Anderson S. and M. Devereux (1988), Trade unions and the choice of capital stock, Scandinavian Journal of Economics 90, 27-44.

Calmfors L. (1982), Employment policies, wage formation and trade union behaviour in a small open economy, Scandinavian Journal of Economics 84, 345-373. 
Calmfors L. and H. Horn (1985), Classical unemployment, accommodation policies, and the adjustment of real wages, Scandinavian Journal of Economics 87, 234 261.

Dertouzos J. N. and J. H. Pencavel (1981), Wage and employment determination under trade unionism: The international typographical union, Journal of Political Economy 89, 1162-1181.

Grossman G. (1983), Union wage, seniority, and unemployment, American Economic Review 73, 277-290.

Heshmati A. (2003), Productivity growth, efficiency and outsourcing in manufacturing and service industries, Journal of Economic Surveys 17(1), 79-112.

Holm P., S. Honkapohja and E. Koskela (1994), A monopoly-union model of wage determination with capital and taxes: An empirical application to the Finnish manufacturing, European Economic Review 38, 285-303.

Horn H. and L. E. O. Svensson (1986), Trade unions and optimal labour contracts, The Economic Journal 96, 323-341.

Kidd D. P. and A. J. Oswald (1987), A dynamic model of trade union behaviour, Economica 54, 355-366.

Kumbhakar S. C., A. Heshmati and L. Hjalmarsson (2002), How fast do banks adjust? A dynamic model of labor-use with application to Swedish banks, Journal of Productivity Analysis 18(1), 79-102.

Lawrence C. and R. Z. Lawrence (1985), Manufacturing wage dispersion: An end game interpretation, Brooking Papers on Economic Activity 47, 47-106.

MaCurdy T. E. and J. H. Pencavel (1986), Testing between competing models of wage and employment determination in unionized markets, Journal of Political Economy 94, S3-S39.

McDonald I. M. and R. M. Solow (1981), Wage bargaining and employment, American Economic Review 71, 896-908.

Nickell S. J. (1986), Dynamic models of labour demand, in: O. Ashenfelter and R. Layard, eds, Handbook of Labour Economics, Vol. II (Elsevier Science Publishers, Amsterdam) 473-522.

Nickell S. J. and M. Andrews (1983), Unions, real wages and unemployment in Britain 1951-1979, Oxford Economic Papers 35, 183-220.

Oswald A. J. (1982a), The microeconomic theory of trade union. The Economic Journal 92, 576-596.

Oswald A. J. (1982b), Wages, trade unions and unemployment: What can simple models tell us? Oxford Economic Papers 34, 526-545.

Oswald A. J. (1985), The economic theory of trade unions: An introductory survey, Scandinavian Journal of Economics 87, 197-225.

Pencavel J. H. (1984), The tradeoff between wages and employment in trade union objectives, Quarterly Journal of Economics 99, 215-231.

Pencavel J. H. (1985), Wages and employment under trade unionism: Microeconomic models and macroeconomic applications, Scandinavian Journal of Economics 87, 197-225.

Pencavel J. H. and B. Holmlund (1988), The determination of wages, employment, and work hours in an economy with centralized wage-setting: Sweden, 1950-83, The Economic Journal98, 1105-1126. 


\section{IZA Discussion Papers}

\begin{tabular}{|c|c|c|c|c|}
\hline No. & Author(s) & Title & Area & Date \\
\hline 674 & $\begin{array}{l}\text { D. A. Cobb-Clark } \\
\text { V. Hildebrand }\end{array}$ & $\begin{array}{l}\text { The Wealth and Asset Holdings of U.S.-Born } \\
\text { and Foreign-Born Households: Evidence from } \\
\text { SIPP Data }\end{array}$ & 6 & $12 / 02$ \\
\hline 675 & $\begin{array}{l}\text { J. Konings } \\
\text { O. Kupets } \\
\text { H. Lehmann }\end{array}$ & $\begin{array}{l}\text { Gross Job Flows in Ukraine: Size, Ownership } \\
\text { and Trade Effects }\end{array}$ & 4 & $12 / 02$ \\
\hline 676 & A. Voicu & $\begin{array}{l}\text { Agriculture: Transition Buffer or Black Hole? A } \\
\text { Three-State Model of Employment Dynamics }\end{array}$ & 4 & $12 / 02$ \\
\hline 677 & $\begin{array}{l}\text { F. Galindo-Rueda } \\
\text { A. Vignoles }\end{array}$ & $\begin{array}{l}\text { Class Ridden or Meritocratic? An Economic } \\
\text { Analysis of Recent Changes in Britain }\end{array}$ & 2 & $12 / 02$ \\
\hline 678 & $\begin{array}{l}\text { M. Barbie } \\
\text { M. Hagedorn } \\
\text { A. Kaul }\end{array}$ & $\begin{array}{l}\text { Fostering Within-Family Human Capital } \\
\text { Investment: An Intragenerational Insurance } \\
\text { Perspective of Social Security }\end{array}$ & 3 & $12 / 02$ \\
\hline 679 & $\begin{array}{l}\text { A. Kölling } \\
\text { C. Schnabel } \\
\text { J. Wagner }\end{array}$ & $\begin{array}{l}\text { Establishment Age and Wages: Evidence from } \\
\text { German Linked Employer-Employee Data }\end{array}$ & 1 & $12 / 02$ \\
\hline 680 & $\begin{array}{l}\text { M. Hagedorn } \\
\text { A. Kaul }\end{array}$ & $\begin{array}{l}\text { Langzeitarbeitslosigkeit in Deutschland: Fakten, } \\
\text { Ursachen und Bekämpfung }\end{array}$ & 7 & $12 / 02$ \\
\hline 681 & $\begin{array}{l}\text { M. Hagedorn } \\
\text { A. Kaul } \\
\text { T. Mennel }\end{array}$ & $\begin{array}{l}\text { An Adverse Selection Model of Optimal } \\
\text { Unemployment Insurance }\end{array}$ & 7 & $12 / 02$ \\
\hline 682 & B. Cockx & $\begin{array}{l}\text { Vocational Training of Unemployed Workers in } \\
\text { Belgium }\end{array}$ & 2 & $01 / 03$ \\
\hline 683 & E. Strobl & $\begin{array}{l}\text { Is Education Used as a Signaling Device for } \\
\text { Productivity in Developing Countries? Evidence } \\
\text { from Ghana }\end{array}$ & 4 & $01 / 03$ \\
\hline 684 & P. A. Puhani & $\begin{array}{l}\text { The Rise and Fall of Swiss Unemployment: } \\
\text { Relative Demand Shocks, Wage Rigidities, and } \\
\text { Temporary Immigrants }\end{array}$ & 2 & $01 / 03$ \\
\hline 685 & $\begin{array}{l}\text { L. Borghans } \\
\text { B. ter Weel }\end{array}$ & $\begin{array}{l}\text { Do We Need Computer Skills to Use a } \\
\text { Computer? Evidence from Britain }\end{array}$ & 2 & $01 / 03$ \\
\hline 686 & $\begin{array}{l}\text { A. S. Kalwij } \\
\text { R. Alessie }\end{array}$ & $\begin{array}{l}\text { Permanent and Transitory Wage Inequality of } \\
\text { British Men, 1975-2001: Year, Age and Cohort } \\
\text { Effects }\end{array}$ & 2 & $01 / 03$ \\
\hline 687 & $\begin{array}{l}\text { I. Haouas } \\
\text { M. Yagoubi } \\
\text { A. Heshmati }\end{array}$ & $\begin{array}{l}\text { Labour-Use Efficiency in Tunisian Manufacturing } \\
\text { Industries }\end{array}$ & 4 & $01 / 03$ \\
\hline 688 & $\begin{array}{l}\text { I. Haouas } \\
\text { M. Yagoubi } \\
\text { A. Heshmati }\end{array}$ & $\begin{array}{l}\text { The Impacts of Trade Liberalization on } \\
\text { Employment and Wages in Tunisian Industries }\end{array}$ & 4 & $01 / 03$ \\
\hline 689 & $\begin{array}{l}\text { A. Heshmati } \\
\text { I. Haouas }\end{array}$ & $\begin{array}{l}\text { The Effects of Union Wage-Settings on Firms' } \\
\text { Production Factor Decisions }\end{array}$ & 5 & 1/03 \\
\hline
\end{tabular}

An updated list of IZA Discussion Papers is available on the center's homepage www.iza.org. 